\title{
Energetic and Exergetic Design Evaluations of a Building Block Based on a Hybrid Solar Envelope Method
}

\author{
Mert Yelda and Saygin Nicel
}

\section{Introduction}

Nowadays, buildings are usually designed with an abstract and single perspective. This study shows that the context in which it will be located and the climate in which it is built also need to be considered.

At all levels of land-use planning decisions, the use of energy has to be taken into account and urban planners have to develop solutions for efficient use of energy. Land-use patterns directly affect energy consumption and influence energy systems. This is seen, for example, from the small scale of "a house" to the large scale of "a country." No matter what the scale of land investigated, it is crucial to understand the significance of efficient energy planning in the contribution to global energy conservation.

When looking from an energy-efficiency point of view, the different properties of the spatial structure are important. The fundamentals exercised when planning and decision making for local energy-efficiency planning are as effective for decisions on a regional scale (Owens 1990). Beside properties like orientation and microclimate on the smaller scale, wider spatial properties are also important on a larger scale. On a small scale, direct forward changes bring considerable improvements, for instance, adjusting the orientation of the building for the sake of energy saving and not adding extra cost to the construction. For comprehensive

\footnotetext{
M. Yelda $(\bowtie)$

Yüzüncü Yil University, Faculty of Engineering and Architecture, Department of City and Regional Planning, Kampüs, Van 65080, Turkey

e-mail: mertyelda@gmail.com

S. Nicel

İzmir Institute of Technology, Faculty of Architecture, Department of City and Regional Planning, Gülbahçe, İzmir 35100, Turkey
} 
energy effectiveness on a larger scale, climatic and microclimatic properties of the urban area have to be considered with great care because of the loads arising from the heating and cooling needs.

It was concluded by Ovalı (2009) in her study that $50 \%$ of energy consumed in buildings can be conserved when a climate-friendly building and built-environment design is applied. The situation in Turkey, where there is only one Building Act, underestimates the effects of different climate regions in the country. According to Act 3030, a building is designed and placed $5 \mathrm{~m}$ from the frontage and $3 \mathrm{~m}$ from flank front. These standards were taken from German standards during the planning of Ankara. However, this plan was for a building in Germany with 2-3 stories, while in Turkey other standards have been implemented so that the distance between the buildings increases $0.5 \mathrm{~m}$ for every storey in the building (Tokuç 2005). Planning, design, and implementation regulations do not take local and regional differences into account. As a result the urban environment is not in harmony with the local properties (Aydemir et al. 2004). Similarly, on a building scale, implementation for the regulation of energy performance in a building only focuses on decreasing the energy demand instead of applying the tools for increasing energy efficiency (Çakmanus 2010), although it deals with issues like the importance of orientation, passive solar gain, and microclimatic effects.

Morello and Ratti (2009) applied a solar envelope method to extensive urban areas and have made this method simple to apply to urban planning. Digital elevation models are used with a computerized method for dealing with this massive model.

Knowles (2003a, b) analyzed the solar enveloped method in detail. Its importance is pointed out in the context of sustainable development and improved esthetic possibilities for architecture and urban design.

When energy-efficient planning and design are taken into consideration, a relationship between land use and building design comes to the mind (Mangan and Oral 2013; Ovalı 2009; Owens 1990) . Energy-efficient planning principles systematically investigate the city on four scales, namely the building (small scale), the neighborhood (building block), the settlement (city), and the region (large scale). Figure 1 shows the basics of this framework and the relationship between energy and spatial properties. The relationship between the dominant properties in energy consumption and scales of investigation is identified and given considering intrinsic energy need and efficient use of energy in the framework. Land-use decisions should be made taking into consideration how to reduce the effects on climate change, ensuring efficient and effective use of energy, and providing sustainable urban policies (Ayan 1985). Moreover, the aim of energy-efficient planning is to help people carry out their daily activities in the most efficient way from an energy point of view, and to minimize energy usage (Owens 1990).

This study aimed to state the amount of energy conservation in a building block when hybrid solar envelope design strategies are applied. In other words, how energy and exergy can be saved when hybrid solar envelope design strategies are applied and what differences that they will bring, compared to the existing design of the building block. 


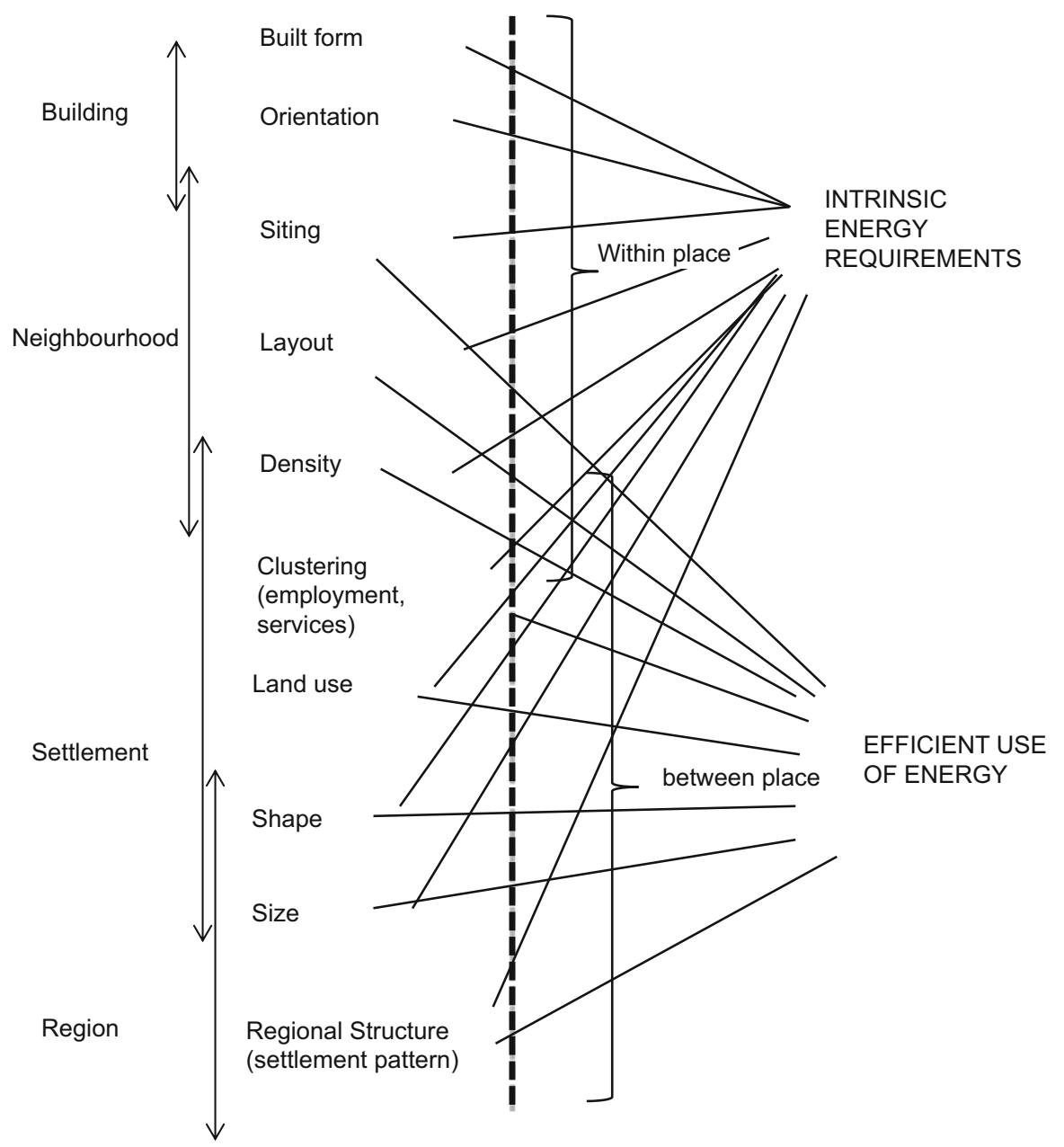

Fig. 1 Framework for analysis of energy/spatial structure relationship (Source: Owens 1990, p. 60)

\section{Hybrid Solar Envelope Method}

The solar envelop method depends on the arrangement of the height of the building(s) in accordance with the sun's path in the effective hours of radiation. The effective sun is the time between 10:00 am and 02:00 pm in which the sun has a greater heating capacity than the other hours of the day. The design is developed according to the angle of sunlight during this period (Canan 2008; Knowles 2003a, b).

The method aims at a scale impact and the height is not limited, only adjusted, depending on the solar angle and the topography. High-rises can also be considered 
with this method (Canan 2008; Knowles, 2003a, b). Generally, a terraced structure is the result of this method being applied to building heights or to a building's singular design.

Various parameters such as physical environmental parameters, which include temperature, wind, sun path, climate, orientation, building form, distance between buildings, building organization, building envelope, and materials and landscaping are taken into account in designing energy-efficient alternatives.

The angle $12^{\circ}$ from south towards east is chosen as the main orientation for a case area (Tokuç 2005) depending on the latitude. Based on the findings in the literature, for a hot-humid climate region optimum building form is taken as 1:1.7 in this study (Olgyay 1973). In the design, the width of the building is chosen as $30 \mathrm{~m}$ and the length as $18 \mathrm{~m}$. Moreover, the long side of the building faces southward to increase the solar gain.

The spacing allowed between the buildings is of particular importance when the shadow effect is taken into account. The building's shadow must not block another building's solar input. The calculation used with this in mind is based on the sun's radiation angle to the earth. In this calculation, the angular value for 21 December is used, as the solar radiation's angle is at its lowest in the year on this date. An angular value of $29^{\circ}$ is used in calculations at $12: 00 \mathrm{pm}$, which is selected as the maximum radiation occurs at noon. Based on the calculations, the $x / y$ ratio must be 0.55 and the maximum shadow length should be 1.96 times the height of the building. In this study the ratio of the spacing between the buildings is thus determined to be a rounded " 2 " in order to prevent a shadow effect.

In addition to the energy-efficient design parameters, a criterion for the solar envelop method is integrated in a single method. This hybrid method includes the requirements of orientation, spacing, landscaping, and building form as well as the building height properties as proposed in the solar envelop method.

Figure 2 shows a calculated solar enveloped for an area. Using these calculated angles of the solar path the building's height is adjusted for achieving maximum use of passive solar energy.

Fig. 2 Solar envelope method (Source: Knowles and Koenig 2002, p. 3)

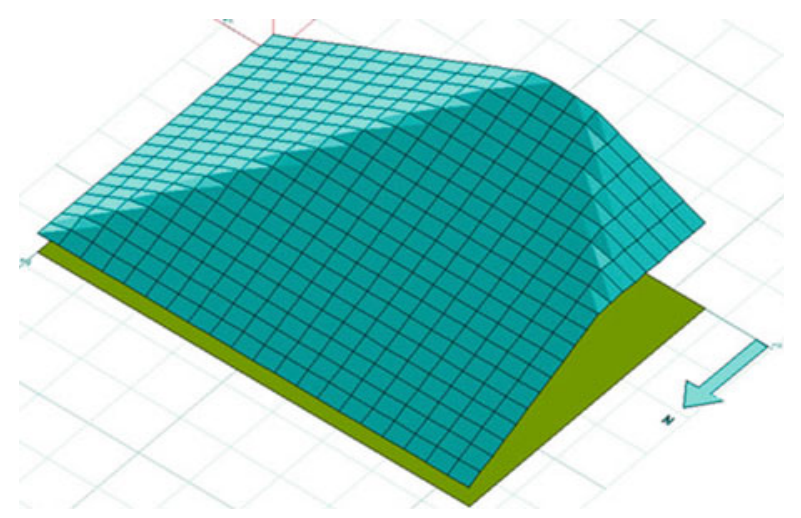



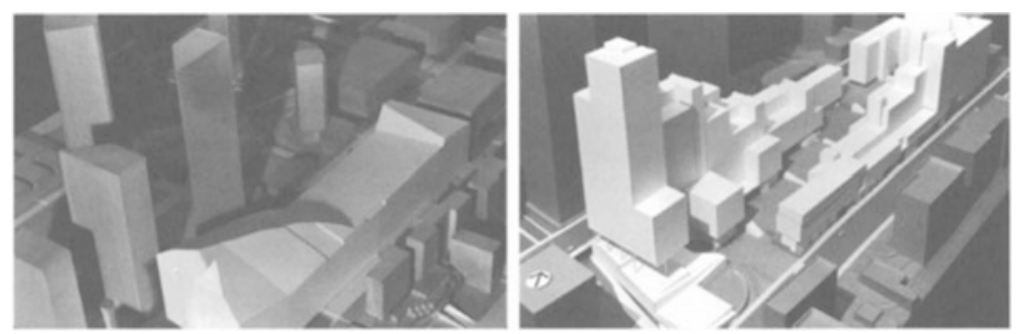

Fig. 3 Solar envelope method in high-rise buildings (Source: Knowles 2003a, p. 13)

The solar envelop method depends on understanding the changing position of the sun throughout the day and year. If this dynamic behavior is a factor in the design of the urban area environmental friendliness, sustainability and reduced energy consumption in cities can be achieved (Canan 2008; Knowles 2003a, b; Topaloğlu 2003). Figure 3 shows an example of an application of a solar envelopedbased design to an urban area. The terraced structure depending on the peak of the solar envelope and the angles of facades can be clearly seen in this design alternative.

\section{Exergy Analysis of a Residential Area}

The calculations for the exergy load of residential building blocks are complicated. This process starts with the data-handling, which is composed of some major design parameters of buildings and building blocks, as listed below (Mert 2014):

- Building scale: location of the building, orientation of the building, building form, area/volume ratio of the building, openings to building ratio, size of the building, design of the building, insulation of the building, resident information, heating and cooling system properties.

- Building block scale: building block form, size of building block, perimeter-toarea ratio, landscaping and planting of building block, microclimatic properties (wind, average temperature, etc.), shadowing due to the configuration of buildings, topography of the building block.

After completion of processing and analyzing data, exergy calculations take place:

- Calculation of the Shadow Effect Factor (SEF).

- Calculation of the exergy load of each building for heating and cooling.

- Calculation of the exergy loads for the building blocks. 


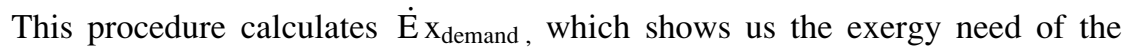
building. For the calculation of exergy demand, the fundamental procedure proposed by LowEx (Hepbaşl1 2012) is used:

$$
\dot{\mathrm{E}} \mathrm{x}_{\mathrm{demand}}=\dot{\mathrm{E}} \mathrm{x}_{\text {loss }}-\dot{\mathrm{E}} \mathrm{x}_{\text {gain }}
$$

The transmission losses through the doors, walls, windows, and roofs cause exergy loss $\dot{\mathrm{E}} \mathrm{x}_{\text {loss }}$;

$$
\begin{gathered}
\dot{\mathrm{E}} \mathrm{x}_{\text {loss }}=\dot{\mathrm{E}} \mathrm{x}_{\text {loss, transmission }}+\dot{\mathrm{E}} \mathrm{x}_{\text {loss, ventillation }} \\
\dot{\mathrm{E}} \mathrm{x}_{\text {loss, transmisson }}=\sum U_{\mathrm{i}} \cdot A_{\mathrm{i}} \cdot\left(T_{\mathrm{i}}-T_{\mathrm{o}}\right)
\end{gathered}
$$

The transmission losses are calculated by taking the heat transfer coefficient of walls, doors, roofs, and ceilings $\left(U_{\mathrm{i}}\right)$ as well as the areas $\left(A_{\mathrm{i}}\right)$ and the indoor $\left(T_{\mathrm{i}}\right)$ and exterior $\left(T_{\mathrm{o}}\right)$ air temperature differences into consideration.

$$
\dot{\mathrm{E}} \mathrm{x}_{\text {loss, ventillation }}=C_{\mathrm{p}} \rho \cdot V \cdot n_{\mathrm{d}} \cdot\left(1-n_{\mathrm{v}}\right) \cdot\left(T_{\mathrm{i}}-T_{\mathrm{o}}\right)
$$

where $\rho$ and $C_{\mathrm{p}}$ are the density $\left[\mathrm{kg} / \mathrm{m}^{3}\right]$ and specific heat $[\mathrm{kJ} / \mathrm{kgK}]$ of air, respectively. $n_{\mathrm{d}}$ and $n_{\mathrm{v}}$ are the air exchange rate $\left[\mathrm{m}^{3} / \mathrm{h}\right]$ and the efficiency constants, respectively. $V$ represents the volume $\left[\mathrm{m}^{3}\right]$.

Solar gains through the openings in the buildings are the source of exergy gain $\left(\dot{E} x_{\text {gain }}\right)$ that is a function of SEF. Other gains, such as lighting $\left(2 \mathrm{~W} / \mathrm{m}^{2}\right)$, that arise from the auxiliary equipment in the settlements are also taken into account. In order to calculate the gain, the determinations of the facades of the buildings are necessary, since the effect of the orientation of the buildings on the energy and exergy performance of the building depends on it. Each separate building is taken into account in this perspective. Facades that face from southwest to southeast and from northwest to northeast are also calculated and taken into consideration correspondingly.

$$
\begin{gathered}
\dot{\mathrm{E}} \mathrm{x}_{\text {gain }}=\dot{\mathrm{E}} \mathrm{x}_{\text {gain, solar }}+\dot{\mathrm{E}} \mathrm{x}_{\text {gain, internal }} \\
\dot{\mathrm{E}} \mathrm{x}_{\text {gain, solar }}=I_{\mathrm{s}} \cdot\left(\frac{100-\mathrm{SEF}}{100}\right) \cdot\left(1-F_{\mathrm{f}}\right) \cdot A_{\mathrm{w}} g
\end{gathered}
$$

Here, solar radiation is shown by $I_{\mathrm{s}}\left[\mathrm{W} / \mathrm{m}^{2}\right], F_{\mathrm{f}}$ is the window frame fraction that is taken as $0.3, A_{\mathrm{w}}$ is the window area $\left[\mathrm{m}^{2}\right]$, and $g$ is the total transmittance.

$$
\mathrm{SEF}=\left(\frac{t_{\text {shadow }}}{t_{\text {daytime }}} 100\right)
$$

The SEF is an indication of a building's blockage by the shadow of other objects and buildings. This is the result of the overlapping shadow on the buildings standing behind another one. The 3D models are used for computing the SEF for both 
summer and winter periods. In SEF, calculation models of the existing situation and the proposed plan are developed separately. These models allow us to simulate the time-dependent effect of the sunlight with regard to the attitude of the case are. SEF is evaluated by determining the ratio of the time under shadow $\left(t_{\text {shadow }}\right.$, [min]) of the building to the daytime ( $\left.t_{\text {daytime }},[\mathrm{min}]\right)$ with direct sunlight access in an approximate manner by using the 3D model of the area.

$$
\dot{\mathrm{E}} \mathrm{x}_{\text {gain }, \text { in }}=n_{\mathrm{o}} \cdot \varphi_{\mathrm{i}, \mathrm{o}}+A_{\mathrm{N}} \cdot \varphi_{\mathrm{i}, \mathrm{e}}
$$

where $\mathrm{n}_{\mathrm{o}}$ is the number of occupants, $A_{\mathrm{N}}$ is the floor area of the building $\left[\mathrm{m}^{2}\right], \Phi_{\mathrm{I}, \mathrm{o}}$ and $\Phi_{\mathrm{I}, \mathrm{e}}$ are specific internal gains of occupants [W/occupant] and specific internal gains of equipment $\left[\mathrm{W} / \mathrm{m}^{2}\right]$, respectively.

$\dot{\mathrm{E}} \mathrm{x}_{\text {input }}$ is calculated by taking $\dot{\mathrm{E}} \mathrm{x}_{\text {demand }}$ into consideration in addition to the efficiency of the heat production and heat distribution systems, which are used as 0.95 and 0.93 , respectively.

The exergy flexibility factor shows the possibility of replacing a thermal system with another system, especially renewable, to meet the exergy demand (Hepbaşli 2012).

$$
\begin{gathered}
\mathrm{EFF}=\frac{\dot{\mathrm{E}} \mathrm{x}_{\text {demand }}}{\dot{\mathrm{E}} \mathrm{x}_{\text {input }}} \\
\dot{\mathrm{E}} \mathrm{x}_{\text {input }}=\frac{\dot{\mathrm{E}} \mathrm{x}_{\text {demand }}}{\eta_{\text {heat_sys }}}+\dot{\mathrm{E}} \mathrm{x}_{\text {loss }}+\dot{\mathrm{E}} \mathrm{x}_{\mathrm{axu}}
\end{gathered}
$$

The heat gains of the buildings are also effective with regard to the values of the cooling exergy load of the building. The average temperature value is taken as $26.8{ }^{\circ} \mathrm{C}$ (MGM 2013) for the summer season.

$$
\dot{\mathrm{E}} \mathrm{x}_{\text {cooling }}=\mathrm{Ex}_{\mathrm{axu}}+\dot{\mathrm{E}} \mathrm{x}_{\text {gain, solar }}+\dot{\mathrm{E}} \mathrm{x}_{\text {gain, transmisson }}
$$

\section{Case Study: Mavişehir Mass Housing Area}

The case area is located in Izmir, which is in the western part of Turkey (Fig. 4). Izmir has a hot-humid climate; the summers are hot and dry while the winters are mild and rainy. According to the climactic and geographic characteristics, both the solar potential and the wind potential of Izmir are noticeably high. July and August are the hottest months in the city, with temperatures of $27.3{ }^{\circ} \mathrm{C}$ and $27.6{ }^{\circ} \mathrm{C}$, respectively; the coldest months are January and February, with temperatures of $8.6{ }^{\circ} \mathrm{C}$ and $9.6^{\circ} \mathrm{C}$, respectively (MGM 2013). 


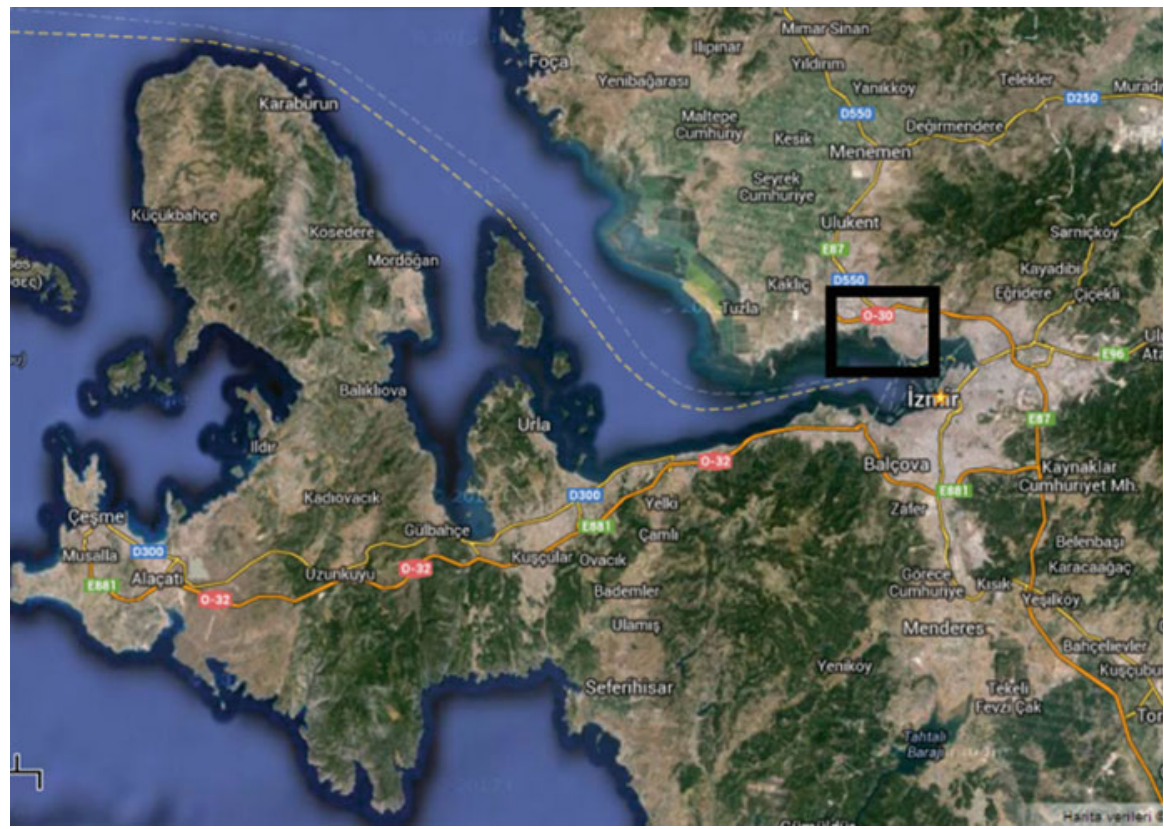

Fig. 4 Location of Mavişehir in Izmir Bay (Source: Google 2013)

Moreover, the prevailing winds in Izmir come from the southeast and the west (MGM 2013; Serin 2011). The prevailing wind direction of the Izmir-Ciğli station was selected for the study because the station is located very close to the case area (Fig. 5).

The sun path diagram of Izmir is given in Fig. 6. The green curve on the upper side of the diagram represents the path of the sun from east to west during the daytime and indicates the angles on 21 June. The blue curve represents the path of the sun on 21 December. As seen in Fig. 6, the angle of sunlight reaching Izmir varies between the maximum angles of $72^{\circ}-29^{\circ}$ at $12 \mathrm{pm}$ during the year.

The existing situation of the selected case area is a mass housing area and consists of high-rise (from 12-storey to 23-storey) buildings (Fig. 7). In addition to the housing units, the area also includes social and leisure facilities such as sports areas, green areas, parking areas, playgrounds, and education and commercial areas. Having a central gas heating system, double-glazed windows, sun blinds, decorative coated doors, and double bathrooms, each type of accommodation in Mavişehir is a luxury residential high-rise apartment or villa (Fig. 8) (Aydoğan 2005; Koç 2001; Özçelik 1998). 
Fig. 5 The prevailing wind direction in Izmir-Ciğli Station (Source: Windfinder 2013)
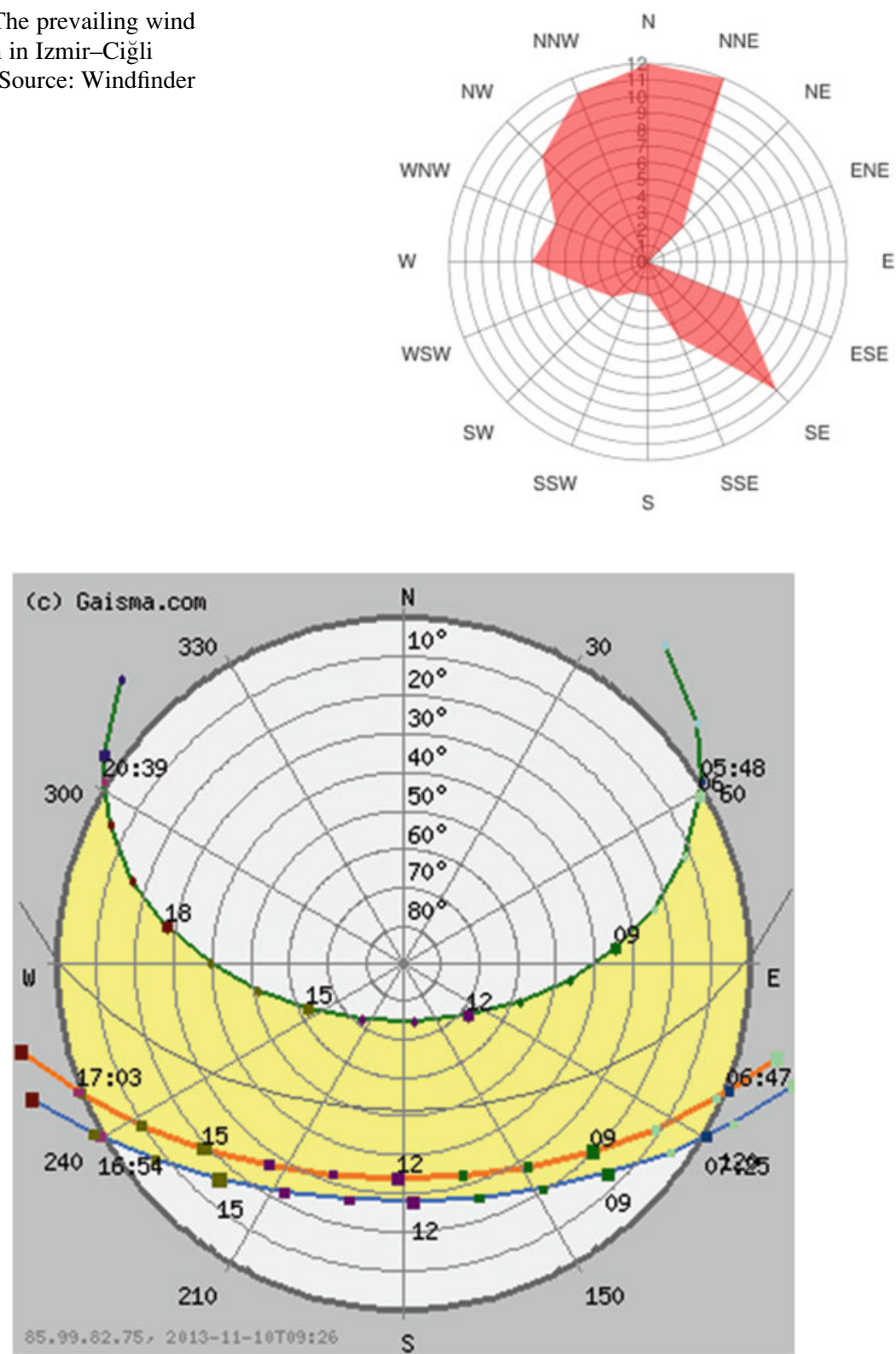

Fig. 6 Sun path diagram of Izmir (Source: Gaisma 2013) 


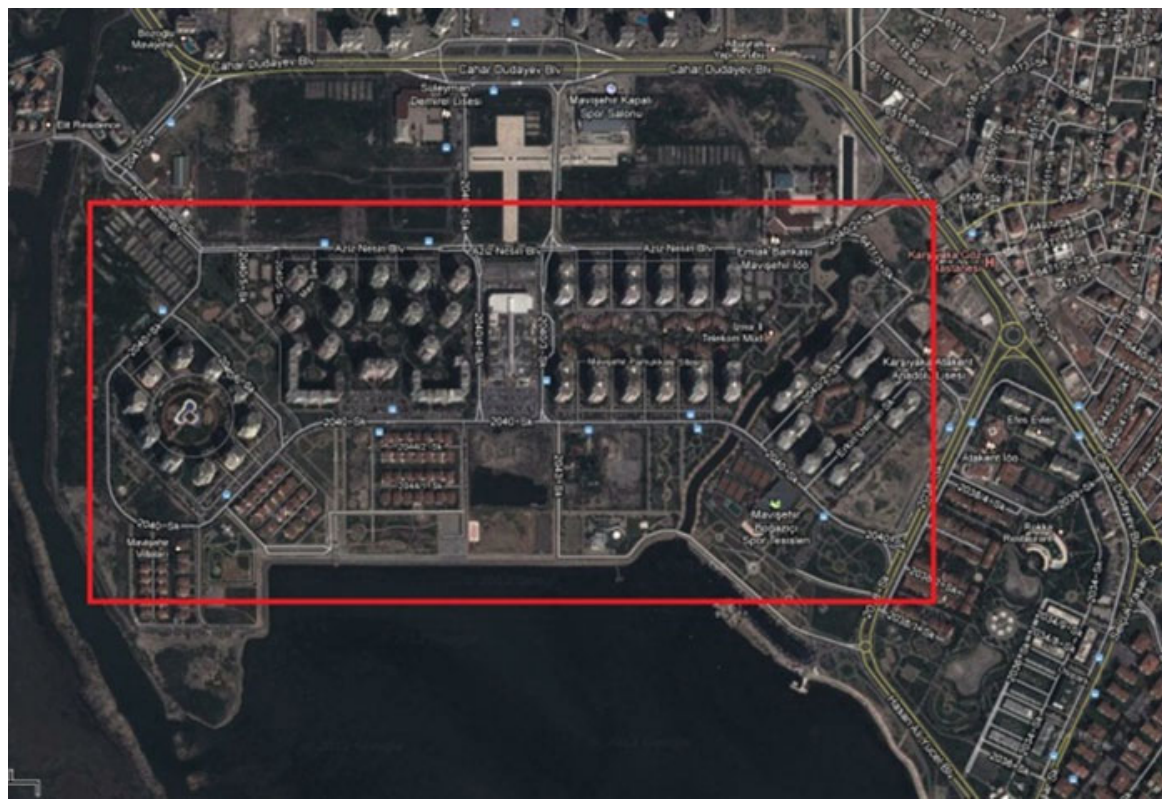

Fig. 7 View of the case area (Source: Google 2013)

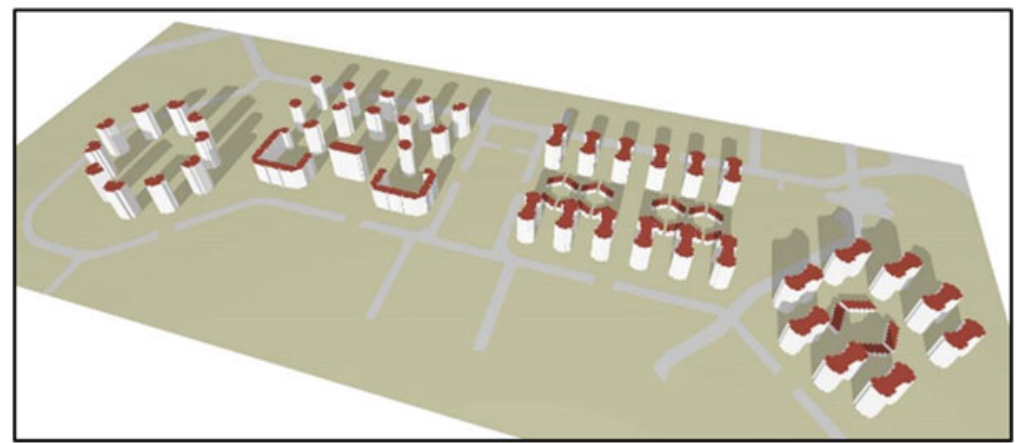

Fig. 8 Site model of the existing building block

\section{Redesign of a Building Block: Hybrid Solar Envelope Method}

The structure of a building block is designed as a terraced structure in accordance with the solar envelope values developed for Izmir (Fig. 6) and the structure of this model. The number of storeys changes within the range of 2 to 12 (Fig. 9) and the area of each housing unit is about $110 \mathrm{~m}^{2}$. This selection is based on the peak point of the solar envelope and the prevailing angles of the solar envelope for east, west, 
Fig. 9 Developed solar envelope of the case area
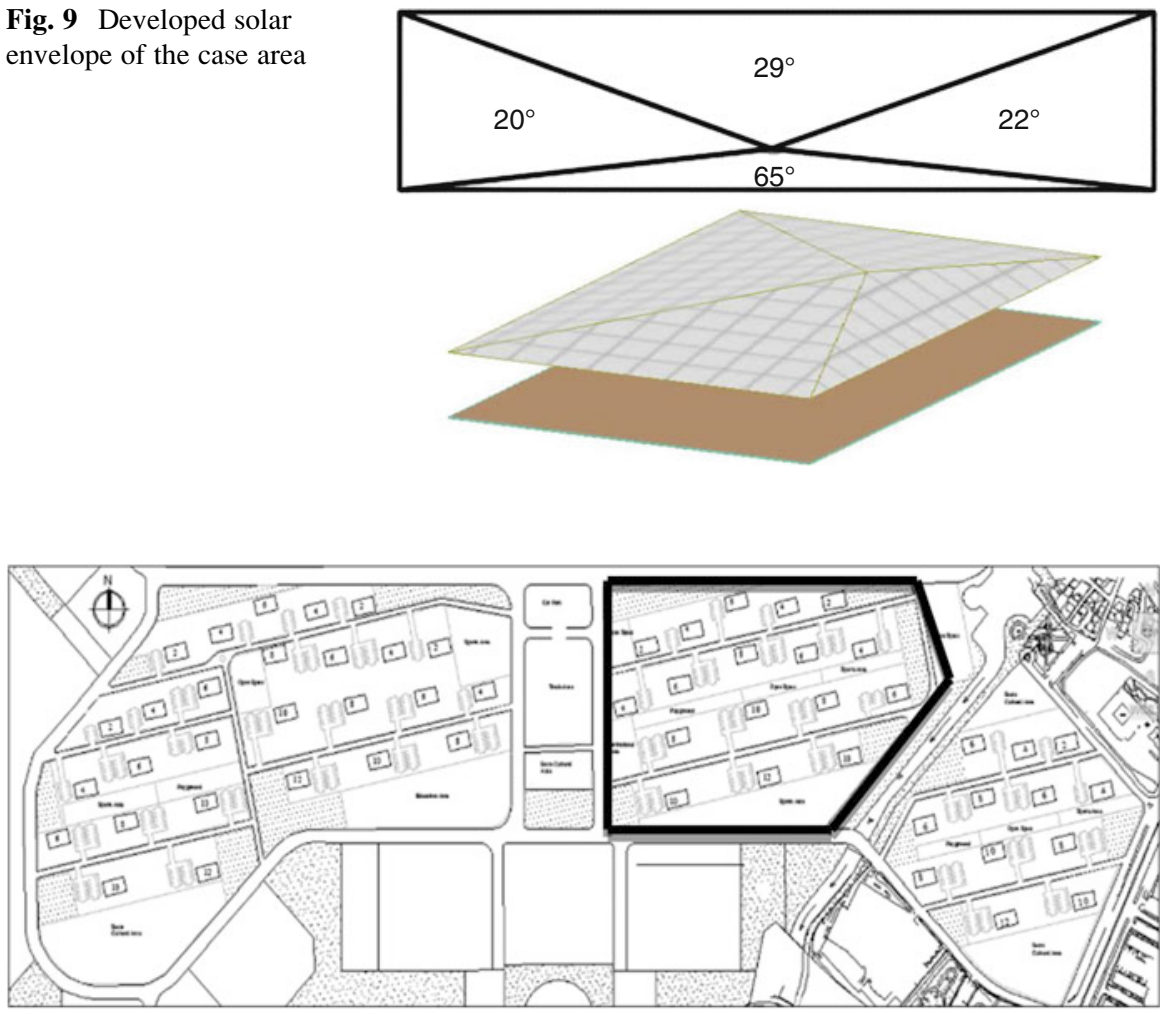

Fig. 10 Site plan of solar envelope-based alternative

north, and south. Green areas, playgrounds, sports area, parking area, and social, cultural, and educational areas are also considered, and areas are demarcated for these needs. The number of storeys of the buildings and height of the buildings change according to the solar envelope calculation. As a result, the distances between the buildings are also affected and changing.

Figures 10, 11, 12, and 13 show the developed site plan in detail for building blocks with regard to the hybrid solar enveloped-based energy-efficient design method. The effect of the solar envelop can be seen in Fig. 12. In Table 1 the number of buildings and housing units in the proposed solar enveloped-based design is shown.

\section{Results and Discussion}

In this study, exergy analysis is used to investigate a building block located in İzmir Mavişehir. Exergy concepts in relation to the environment ease the quantification of economic and ecological problems by underlining the potential of a successful 


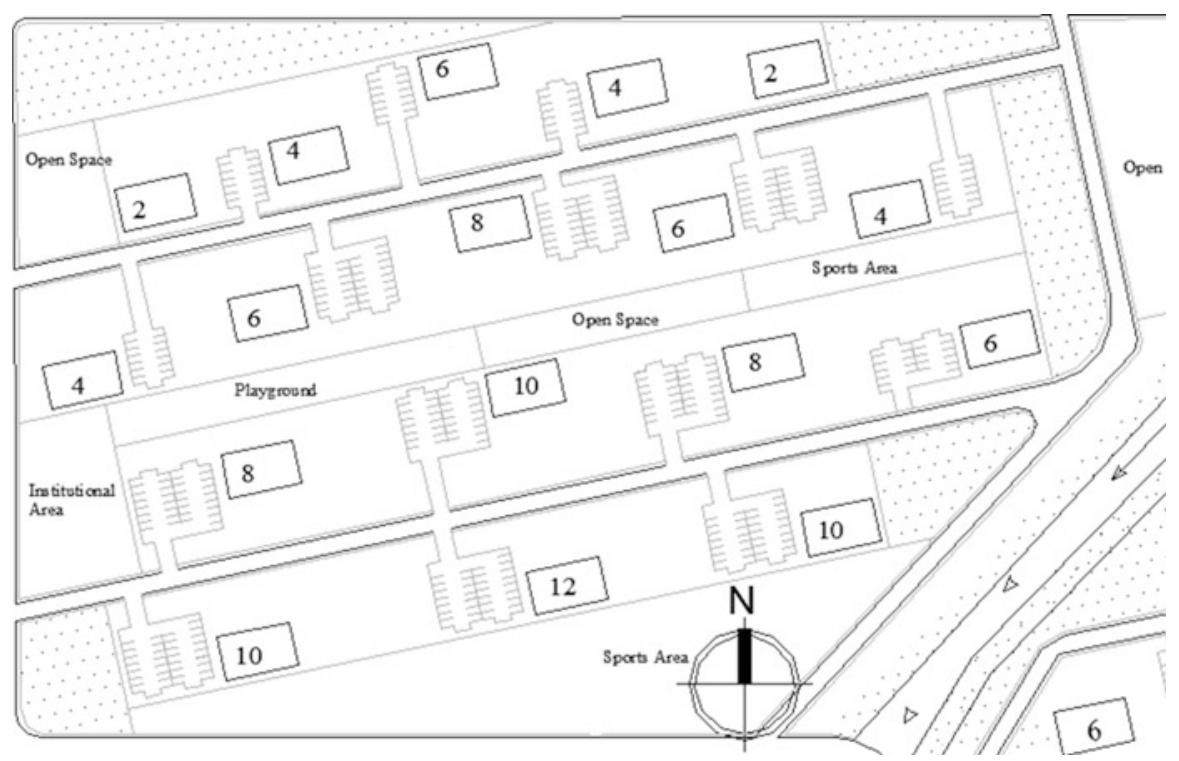

Fig. 11 Site plan of solar envelope-based alternative in detail

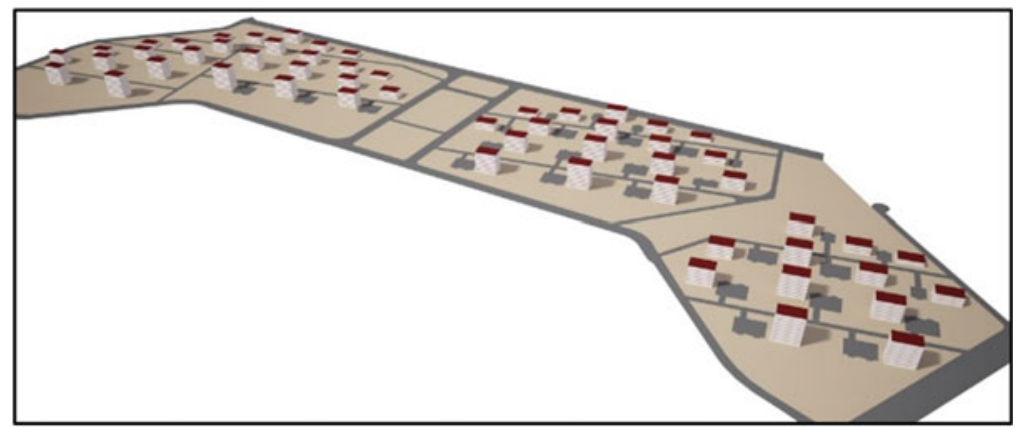

Fig. 12 Site model of solar envelope-based alternative

exergy analysis (Mert 2006). The important effects of the relationship between exergy and the environment are seen in the reduction of waste energy emissions, a decrease in resources of energy-related sectors, and more efficient use of energy (Dinçer 2002).

Some assumptions made in the analysis are listed below:

- The reference state for exergy analysis is selected as $298 \mathrm{~K}$ temperature and $1 \mathrm{~atm}$ pressure in atmospheric concentrations.

- Indoor air temperature is $21^{\circ} \mathrm{C}$.

- Outdoor temperature is $10.9{ }^{\circ} \mathrm{C}$, the average winter temperature of Izmir (between the years of 1960-2012) (MGM 2013). 


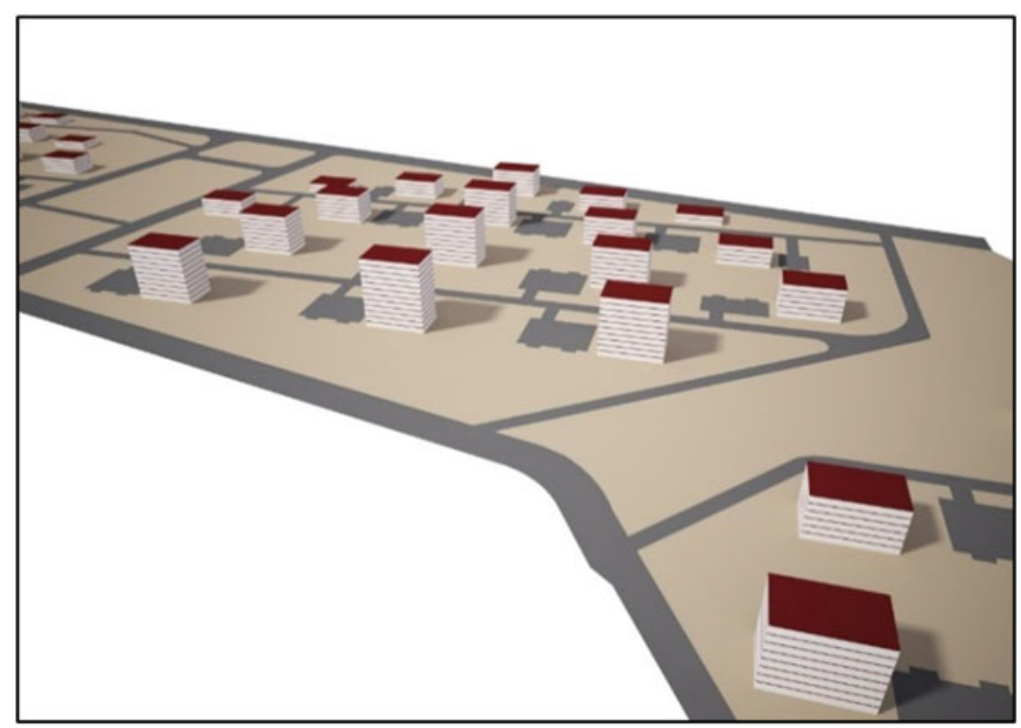

Fig. 13 Site model of solar envelope-based alternative

Table 1 Details for the solar envelop-based design

\begin{tabular}{l|l|l}
\hline Storey & No. of buildings & No. of housing units \\
\hline 12 & 4 & 192 \\
\hline 10 & 9 & 360 \\
\hline 8 & 11 & 352 \\
\hline 6 & 13 & 312 \\
\hline 4 & 12 & 192 \\
\hline 2 & 7 & 56 \\
\hline Total & $\mathbf{5 6}$ & $\mathbf{1 4 6 4}$ \\
\hline
\end{tabular}

- Outdoor temperature is $28.6{ }^{\circ} \mathrm{C}$, the average summer temperature of Izmir (MGM 2013).

- The heat transfer coefficients of the walls and doors are gathered from real values depending on the plan details of the buildings, which are obtained from the Karşıyaka Municipality, and on the reported data of the construction company (Karşıyaka Municipality 2012).

- An average value of four residents is assumed during the calculations.

- $70^{\circ} / 50^{\circ}$ heating system (inlet/outlet temperature of the radiators) is used in calculations in accordance with the reality and the condensing boiler systems.

In Table 2 results for exergy analysis of a residential area for solar envelopebased design is given. It must be mentioned that the summer exergy load and winter exergy load is in accordance with the expectation that cooling load is higher than the heating load and the exergy efficiency is in the range of 7-11, depending on the 
Table 2 Results for the solar envelop-based design

\begin{tabular}{l|l|l|l|l|l}
\hline Storey & $\begin{array}{l}\text { Exergy load } \\
\text { summer [W] }\end{array}$ & $\begin{array}{l}\text { Exergy load } \\
\text { winter [W] }\end{array}$ & $\begin{array}{l}\text { Exergy by } \\
\text { fuel [W] }\end{array}$ & $\begin{array}{l}\text { Exergy } \\
\text { efficiency } \\
{[\%]}\end{array}$ & $\begin{array}{l}\text { Exergy flexibility } \\
\text { factor [\%] }\end{array}$ \\
\hline 12 & 16,753 & 8,330 & 6,200 & 10.1 & 39 \\
\hline 10 & 14,048 & 7,078 & 5,183 & 10.5 & 38 \\
\hline 8 & 9,848 & 5,425 & 3,438 & 10.9 & 36 \\
\hline 6 & 8,638 & 4,575 & 3,148 & 11.0 & 33 \\
\hline 4 & 5,932 & 3,323 & 2,131 & 11.2 & 29 \\
\hline 2 & 3,227 & 2,071 & 1,113 & 7.4 & 19 \\
\hline
\end{tabular}

Fig. 14 Exergy load and exergy according to fuel values of proposed alternative and existing plans

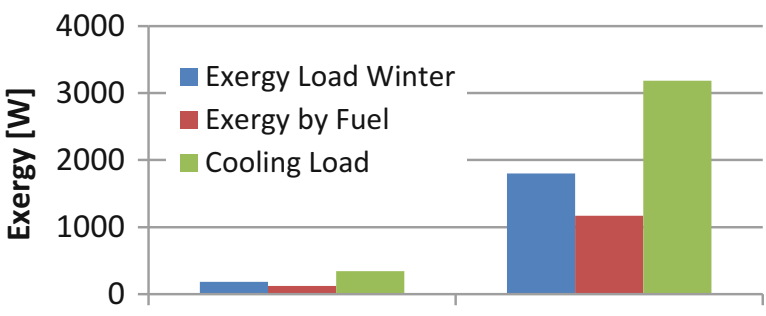

Solar Envelope Based Design Existing Plan

local climate properties. The higher the building height the larger the exergy loads, whereas lower exergy loads are also seen in the investigation.

The exergy efficiency values are in the range of 10.8-11.2\% and the exergy by fuel value changes from $2,845.7$ to $5,424.9 \mathrm{~kW}$. These results are in accordance with the literature, as Hepbaşlı (2012) pointed out that the efficiency of buildings with a LowEx design reaches $7-8 \%$. When the existing plan and the proposed plan alternative are compared it is seen that the exergy load value for the existing plan is ten times higher than the new design. It can be seen that the hybrid solar envelope design can lead to high ratios of energy conservation. In Fig. 14, the exergy per separate housing unit is shown. It is seen that a solar enveloped-type housing has better energy conservation with lower than $184 \mathrm{~W}$, while in the existing plan this value lies in the range of 1,800 W. The proposed design's exergy load values are lower than the others mainly because of the general high performance of the heating system in a great number of housing units. This investigation is carried out per housing unit since the housing unit numbers are different in the proposed design alternative and to the existing situation. So in order to achieve a logical discussion, comparison per housing unit is applied.

From a cooling load point of view in the summer period, it is seen that the saving is much higher since the exergy load value decreases from 3,181 to 346 . This is a result of proper airing and particularly use of excellent construction materials (Table 3). When the values from the literature (Hepbaşl1 2012) of cooling loads are investigated it is seen that cooling loads for hot-humid zones are higher than heating loads and it is seen that the results of this study are in accordance with the literature. 
Table 3 The savings by energy-efficient design per housing unit

\begin{tabular}{l|l|l}
\hline & Solar envelope based design & Existing plan \\
\hline Exergy load winter [W] & 184.80 & 1798.0 \\
\hline Exergy by fuel [W] & 125.37 & 1173.0 \\
\hline Exergy load summer [W] & 346.89 & 3181 \\
\hline
\end{tabular}

Table 4 The annual saving using an energy-efficient design

\begin{tabular}{l|l}
\hline Conservation type & Conservation amount (per year) \\
\hline Exergy winter $[\mathrm{W}]$ & $2,188.67$ \\
\hline Exergy summer $[\mathrm{W}]$ & $1,583.68$ \\
\hline Money $[\mathrm{TL}]$ & $1,072.48$ \\
\hline $\mathrm{CO}_{2}$ emission $[\mathrm{kg}]$ & $1,787.46$ \\
\hline
\end{tabular}

Table 5 Design values of existing and proposed plan alternatives

\begin{tabular}{l|l|l}
\hline & Existing building block & Solar envelop-based building block \\
\hline Number of buildings & 155 & 56 \\
\hline Housing unit (number) & 5320 & 1464 \\
\hline Floor area of housing unit $\left(\mathrm{m}^{2}\right)$ & $56 \mathrm{~m}^{2}-150 \mathrm{~m}^{2}$ & $117 \mathrm{~m}^{2}$ \\
\hline Total housing area $\left(\mathrm{m}^{2}\right)$ & 54,135 & 30,240 \\
\hline
\end{tabular}

The amount of money and greenhouse emissions saved is shown in Table 4 per housing unit in the building block. It is seen that every housing unit saves 1,072.48 TL (nearly US\$500) in a year according to the effect of the energy-efficient design. This value is very important for most of the families in Turkey. Of more importance than the monetary savings, nearly 1.79 tons of greenhouse gas emissions per housing unit have not been emitted into the atmosphere, which is a magnificent contribution to the environment for the sake of a sustainable and green future. These values are calculated using the energy price of US $\$ 0.08 / \mathrm{kW}$ for cost and using reaction stoichiometry calculations with natural gas as the fuel in the case area.

The exergy calculations are concluded with determinations of exergy efficiency and exergy loads in addition to the annual conservation of exergy, money, and greenhouse gases.

In Table 5, general features of the existing building block and the proposed design alternative are summarized. The design alternative has less housing units than the existing building block. As seen in Table 3, the housing unit number is decreased in the alternative proposed design. This result mostly arises from the fact that the spacing between the buildings is increased in the energy-efficient design, which brings a low density to the built area. 
From an energy-efficiency point of view it is seen from this study that when the planning and design are carried out taking into consideration the energy-efficient design parameters, the efficiencies increase considerably. That brings us to a position to propose considering these parameters in every planning and design study as well as implementing these in building and planning acts.

\section{Conclusions}

The building block is redesigned in order to increase energy. The results of the exergy analysis of the proposed design alternative show that the exergy efficiency values have increased to $11 \%$ from $1.5 \%$ in the existing design. Since the efficiency value is the representation of the performance of using the energy in an effective manner, it is free of the magnitude (size of the area) and can be evaluated for understanding the energetic behavior of the existing and proposed design alternative. The exergy efficiency was increased considerably, and a large amount of energy and money can be conserved through the application of the proposed design. The results also show that the annual exergy load of a single housing unit was decreased from 1,800 to $184.8 \mathrm{~W}$ for winter and from 3,180 to $346 \mathrm{~W}$ in summer.

It is seen that when energy-efficient design parameters are taken into account, such as proper distance allocation among the buildings for sunlight purposes, a lower density building block is needed. In the existing plan the parking area is also larger than the proposed building block because of the high number of housing units. Moreover, the high housing unit number creates a decrease in the green open spaces, sports areas, and playground areas. It was also found out that the alternative design proposed larger green areas, open spaces, and social areas with respect to the existing situation in the area. That also mostly arose from the spacing between the buildings.

As a result of this study, it was found that by applying a solar envelope design to the selected building block, 1,613 and 2,834 W of energy could be conserved during the winter and the summer periods, respectively, for a housing unit. With this energy conservation, 1,072 TL (nearly US\$500) per housing unit was saved annually. Of more importance, $1,787 \mathrm{~kg}$ of emission gases $\left(\mathrm{CO}_{2}\right.$, etc. $)$ per housing is not released into the atmosphere. This results in the formation of a more sustainable neighborhood. When the total area is taken into account, the exergy efficiency reaches up to $11 \%$. The Exergy by Fuel Value is $125.37 \mathrm{~kW}$, with a Summer Exergy Load of $346.89 \mathrm{~kW}$ and a Winter Exergy Load of $184.80 \mathrm{~kW}$. These are the main indications of the importance of the exergetic analysis in a building block.

In this study, it is revealed that according to energy efficiency, efficiencies increase considerably when a hybrid solar envelope design is considered during the planning and design periods. Furthermore, the results show that the concept of energy efficiency should be taken seriously from every urban planning and design stage to implementation. 


\section{References}

Ayan, M.: Konut Alanları Tasarım İlkeleri. Batıkent Konut Üretim Yapı Kooperatifleri Birliği, Ankara (1985)

Aydemir, Ş., Erkonak, A., Şen, S., Beyazlı, D.Ö., Öksüz, N., Ahmet, M., Sancak, C., Özyaba, M., Türk, Y.A.: Kentsel Alanların Planlanması ve Tasarımı. Akademi Kitabevi, Trabzon (2004)

Aydoğan, A.: Residential satisfaction in high-rise buildings. Master diss., İzmir Institute of Technology (2005)

Çakmanus, İ.: Binalarda Enerji Verimliliğinin Değerlendirilmesi. Yeşil Bina. 4, 1-3 (2010)

Canan, F.: Enerji etkin tasarımda parametrelerin denetlenmesi için bir model denemesi. Unpublished PhD Thesis, Selçuk University (2008)

Dinçer, İ.: The role of exergy in energy policy making. Energy Policy. 30, 137-149 (2002)

Gaisma. Sun path diagram. http://www.gaisma.com (2013). Accessed on 3 Nov 2013

Google Earth.: http://www.google.com/earth/ (2013). Accessed on 3 Feb 2013

Hepbaşl1, A.: Low Exergy (LowEx) heating and cooling systems for sustainable buildings and societies. Renew. Sust. Energ. Rev. 16, 73-104 (2012)

Karşıyaka Municipality: Approved plan of Mavişehir mass housing. Accessed on June, 2012, Department of Planning Archive (2012)

Knowles, R.: The solar envelope in time-saver standards for urban design. The McGraw-Hill Companies, New York (2003a)

Knowles, R.L.: The solar envelope: its meaning for energy and buildings. Energ. Build. 35(1), $15-25$ (2003b)

Knowles, R., Koenig, P.: A dynamic approach to solar-access zoning. School of Architecture, University of Southern California, Los Angeles (2002)

Koç, H.: Cumhuriyet Döneminde İzmir'de Sosyal Konut ve Toplu Konut Uygulamaları. Dokuz Eylül University Faculty of Architecture Publications, Izmir (2001)

Mangan, S.D., Oral, G.K.: Türkiye'nin Farklı İklim Bölgelerinde Bir Konut Binasının Enerji Etkin İyileştirilmesi. In 11.Ulusal Tesisat Mühendisliği Kongresi, Izmir, 921-931 (2013)

Mert, S.O.: Exergoeconomic analyisis of pem fuel cell systems for transportation application. Unpublished Master diss., Ege University (2006)

Mert, Y. Application of exergy analysis method to energy efficient building block design. Unpublished PhD Thesis, IYTE (İzmir Institute of Technology) (2014)

MGM (Turkish State Meteorology Service).: İklim Sınıflandırması.. http://www.mgm.gov.tr/ iklim/iklim-siniflandirmalari.aspx?m=IZMIR (2013). Accessed on 3 Sept 2013

Morello, E., Ratti, C.: Sunscapes: 'solar envelopes' and the analysis of urban DEMs. Comput. Environ. Urb. Syst. 33(1), 26-34 (2009)

Olgyay, V.: Design with climate-bioclimatic approach to architectural regionalism. Princeton University Press, New Jersey (1973)

Ovalı, P.K.: Türkiye İklim Bölgeleri Bağlamında Ekolojik Tasarım Ölçütleri Sistematiğinin Oluşturulması- "Kayaköy Yerleşkesinde Örneklenmesi. PhD diss., Trakya University (2009)

Owens, S.: Land use planning for energy efficiency. In: Cullingworth, B. (ed.) Energy, land and public policy, energy policy studies, vol. 5, pp. 53-98. Transaction Publishers, New Jersey (1990)

Özçelik, A.A.: İzmir'deki Toplu Konutların Türkiye Emlak Bankası Uygulamaları Örneğinde İrdelenmesi. Master diss., Dokuz Eylül University (1998)

Serin, E.: Ekolojik Konut Tasarımı Kriterlerinin Araştırılması ve İzmir İli İçin Bir Tasarım Modeli Önerisi. Master diss., Dokuz Eylül University (2011)

Tokuç, A.: İzmir'de Enerji Etkin Konut Yapıları İçin Tasarım Kriterleri. Master diss., Dokuz Eylül University (2005).

Topaloğlu, B. Solar envelope and form generation in architecture. Unpublished Master diss., Middle East Technical University (2003)

Windfinder.: Wind \& weather statistics for Izmir-Ciğli. www.windfinder.com (2013). Accessed on 3 Nov 2013 